\title{
Physiological behavior of bean's seeds and grains during storage
}

\author{
FLÁVIA D.R. CASSOL ${ }^{1}$, ANDRÉA M.T. FORTES ${ }^{1}$, LORENA C. MENDONÇA ${ }^{2}$, \\ CAMILA V. BUTURI ${ }^{2}$ and THAÍS R. MARCON ${ }^{1}$
}

\author{
${ }^{1}$ Programa de Pós-Graduação em Engenharia Agrícola/PGEAGRI, Centro de Ciências Exatas e Tecnológicas, \\ Universidade Estadual do Oeste do Paraná, Rua Universitária, 2069, 85819-110 Cascavel, PR, Brasil \\ ${ }^{2}$ Laboratório de Fisiologia Vegetal, Centro de Ciência Biológicas e da Saúde, Universidade Estadual \\ do Oeste do Paraná, Rua Universitária, 2069, 85819-110 Cascavel, PR, Brasil
}

Manuscript received on December 12, 2014; accepted for publication on July 29, 2015

\begin{abstract}
Beans are one of the most used foods to meet the energy needs of the Brazilian diet, requiring farmers to use high seed physiological potential. The aim was to evaluate the physiological quality of beans stored for 360 days. Analyses were performed at 0,30, 90, 180, 270, and 360 days after receiving the seeds (S1 and S2) and grains (G1 and G2) of BRS Splendor. Tests of germination, accelerated aging, cold, speed of germination, average length of shoots, and root were performed. The experimental design was completely randomized split-plot in time and the means were compared through Tukey test at 5\% probability. Seed germination was not affected in S2, while the drop in S1 and G1 was significant. The vigor of grains from field 1 declined from 91 to $50 \%$ and from $93 \%$ to $76 \%$ by accelerated aging and cold, respectively, after 360 days. The germination speed tests performed showed a decreased during the experiment. The grains from field 1 had lower physiological quality. The accelerated aging and cold tests, through the speed of germination parameter, showed decrease in the vigor of the Splendor BRS. The storage period influenced the physiological quality of the beans tested.
\end{abstract}

Key words: germination, Phaseolus vulgaris L., physiological quality, vigor.

\section{INTRODUCTION}

Beans (Phaseolus vulgaris L.) are one of the most important foods used to supply Brazilian's energetic needs (Toledo et al. 2009). Brazil is the biggest producer of this legume, producing approximately 3500.4 thousand tons with productivity of $907 \mathrm{~kg}$ $\mathrm{ha}^{-1}$ for harvest 2011/2012 (CONAB 2012).

Bean low productivity, when compared to other producing countries, may be related to the

Correspondence to: Flávia Danieli Rech Cassol

E-mail: fdrcassol@yahoo.com.br low rate of certified seeds used on planting (Marcos Filho 2005). According to Carvalho and Nakagawa (2000), seeds are a living entity, and when carried in the field, aim to ensure specie's reproduction and endurance, while the grains are produced intended to consumption as food.

Seeking more income, bean producers are searching cultivars with faster germination and high vigor (Maia et al. 2011). Thus, the physiological potential evaluation, is a very important factor and aims to guarantee that the seeds have necessary vigor that allows a direct relationship with the culti- 
vation (Coimbra et al. 2009), under a wide range of environmental conditions, through reliable, quick and reproducible tests (Binotti et al. 2008).

Germination test is a standard method for determining physiological potential of seeds, being conducted in optimum conditions (Marcos Filho 2005). Along with this test, said Nakagawa (1999), seedling evaluation can be performed, such as germination velocity and seedling growth. The result of these evaluations expresses the assessed seeds vigor.

For Soares et al. (2010) accelerated aging and cold are considered important vigor tests. They evaluate seeds behavior under stress conditions and are performed in high humidity conditions. The first one is conducted in high temperature, which is related to their deterioration rate increase (Marcos Filho 2005, Binotti et al. 2008). While the cold test is performed in low temperature, simulating factors that can occur on the planting season (Marcos Filho 2005).

Therefore, quick evaluations allows greater promptness on the results, thus, the decisions regarding production, storage and marketing can be made more efficiently (Fessel et al. 2010, De Bittencourt et al. 2012). Because the seed aging results from physiological potential decay, occurs germination ability decrease and an environmental stress sensibility increase. (Marcos Filho 2005).

After reaching the maximum physiological quality, on beans and other species, naturally an irreversible and continuous process of deterioration begins. This can be delayed trough appropriate process of storage (Carvalho and Nakagawa 2000, Palabiyik and Peksen 2008, Cardoso et al. 2012). According to Resende et al. (2008), usually bean storage happen in inappropriate conditions, resulting qualitative and quantitative losses.

Thus, the aim of this work was to evaluate the physiological behavior of bean's seeds and grains of cultivar BRS Splendor, stored under not controlled environmental conditions for 360 days.

\section{EXPERIMENTAL PROCEDURES}

The evaluated cultivar was BRS Splendor (Phaseolus vulgaris L., black group), second harvest (dry) de 2011, from two farms of Cascavel city, field 1 (24 53' 49.9' $\mathrm{S}$ and $53^{\circ} 31^{\prime} 36.1^{\prime \prime} \mathrm{W}$ ) and field 2 $\left(24^{\circ} 49^{\prime} 36.0^{\prime \prime} \mathrm{S}\right.$ and $\left.53^{\circ} 32^{\prime} 29.1^{\prime \prime} \mathrm{W}\right)$, in western Paraná.

The fields were being used for seeds reproduction and, as established by Agriculture Ministry (Brasil 2011), the three meters around the area, can only be marketed for consumption (grain). Thereby, the beans were classified as: field seeds 1 (S1), field seeds 2 (S2), field grains 1 (G1) and field grains 2 (G2).

At the processing unit, the beans were submitted to a pre-cleaning, drying and classification. Next, they were separated and stored in the lab, into paper Kraft bags, under not controlled environmental conditions for 360 days. When arrived and after $30,90,180,270$ and 360 days the samples were submitted to the following evaluations.

In accordance with the indicated method of Rules for Seeds Analyze - RAS (Brasil 2009), these tests were conducted: Mass of 100 seeds; Water content: through standard oven method, also verified after the accelerated aging test, as recommended by Marcos Filho (2005).

For the germination test, "germitest" paper was used as substrate, dampened with distilled water (2.5 times weight), 50 seeds were laid on it; the resulting rolls were placed in a sprouting camera at $25 \pm 1{ }^{\circ} \mathrm{C}$, for seven days (Brasil 2009). Germinated beans counting was daily, until seedlings number stabilization (Nakagawa 1999) and the germination velocity index (GVI) was calculated according to Maguire (1962). On the last day of the germination test evaluation, five normal seedlings were taken from every replicated; then average root length (ARL) and average length of aerial part (ALAP), were measured.

On the accelerated aging test, beans were distributed on single-layer, atop a stainless steel 
surface, and placed in plastic boxes (gerbox) containing $40 \mathrm{~mL}$ of distilled water on bottom and kept at $42{ }^{\circ} \mathrm{C}$ of temperature, for 24 hours, in sprouting camera. After that, they were evaluated according to the germination test (Marcos Filho 1999).

The cold test was performed trough Barros et al. (1999) method, in accordance with the germi- nation test and the rolls were kept under a $10{ }^{\circ} \mathrm{C}$ temperature for three days, as indicated by Miguel and Cícero (1999). After this time, the camera temperature was increased to $25^{\circ} \mathrm{C}$ and the evaluations were done according to the germination test.

Meteorological data of precipitation, relative humidity and maximum and minimum temperature are presented on Figure 1.

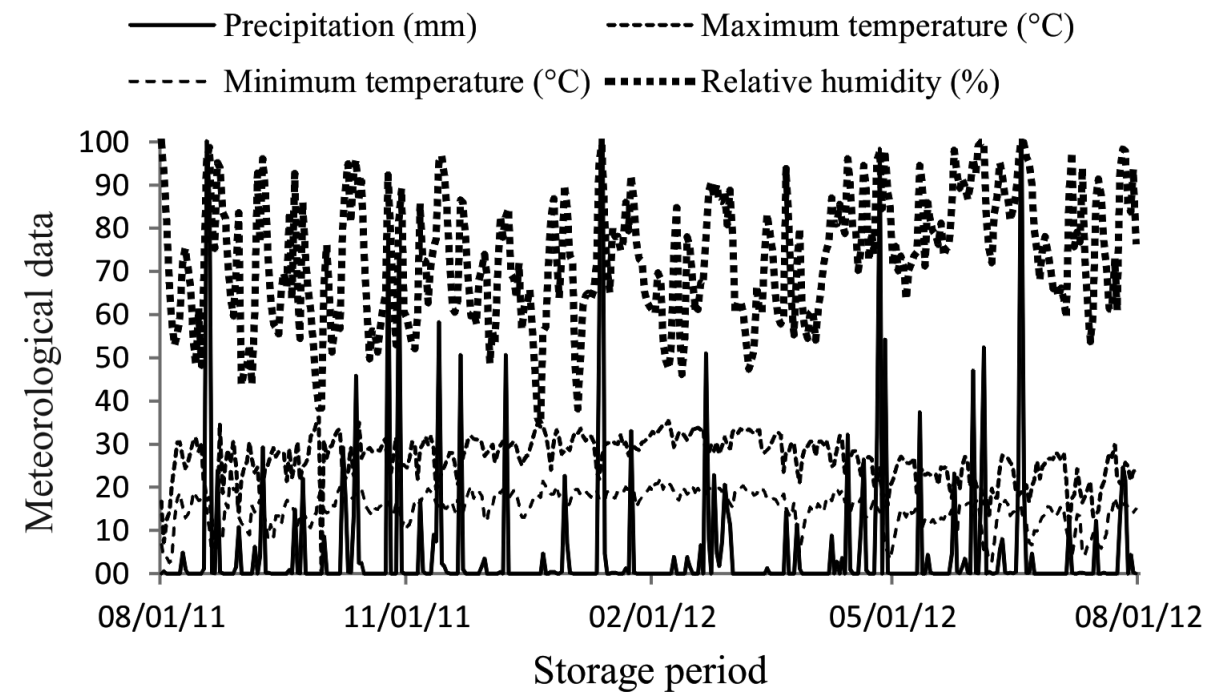

Figure 1 - Daily precipitation data ( $\mathrm{mm})$, relative humidity (\%) and maximum and minimum temperature $\left({ }^{\circ} \mathrm{C}\right)$ during experimental time 1 (SIMEPAR 2012). Cascavel, PR-2013

A completely randomized design was used (CRD) in plots subdivided by time, with four repetitions. Abnormal data were transformed by $\sqrt{ } \mathrm{x}+0.5$, and values expressed in percentage were transformed by arc sin $\sqrt{x} / 100$ (Banzatto and Kronka 1995, Brasil 2009).

The results were submitted to analysis of variance (ANOVA) and the average compared trough Tukey test, 5\% probability level, software $\mathrm{R}$, version 2.15.1 (R Development Core Team 2011) and the regression analysis was tested trough Sisvar ${ }^{\circledR}$ software, version 5.3 (Ferreira 2008).

\section{RESULTS AND DISCUSSION}

The average values found to variable mass of 100 seeds did not show interaction with storage period.
The means were statistically equals and varied between 18.8 and $20.6 \mathrm{~g}$ to $\mathrm{S} 1 ; 20.4$ and $22.3 \mathrm{~g}$ to S2; 20.9 and $22.9 \mathrm{~g}$ to $\mathrm{G} 1$; and 20.4 and 21.9 $\mathrm{g}$ to G2. Similar results were found by Avaci et al. (2010), whose variable showed no statistically difference after 30 days and by Cassol et al. (2012), whose 90 days of storage period didn't affect the beans batches.

There was significant interaction between the factors to water content, represented in the regression model, Figure 2. It should be noted decrease of this variable until the 90 days of evaluation, also observed on storage beans of "red" cultivar by Resende et al. (2008) after 112 and by Rigueira et al. (2009) after 120 days.

After 180 days of storage the hydration of seeds and grains occurred, reaching the same level 


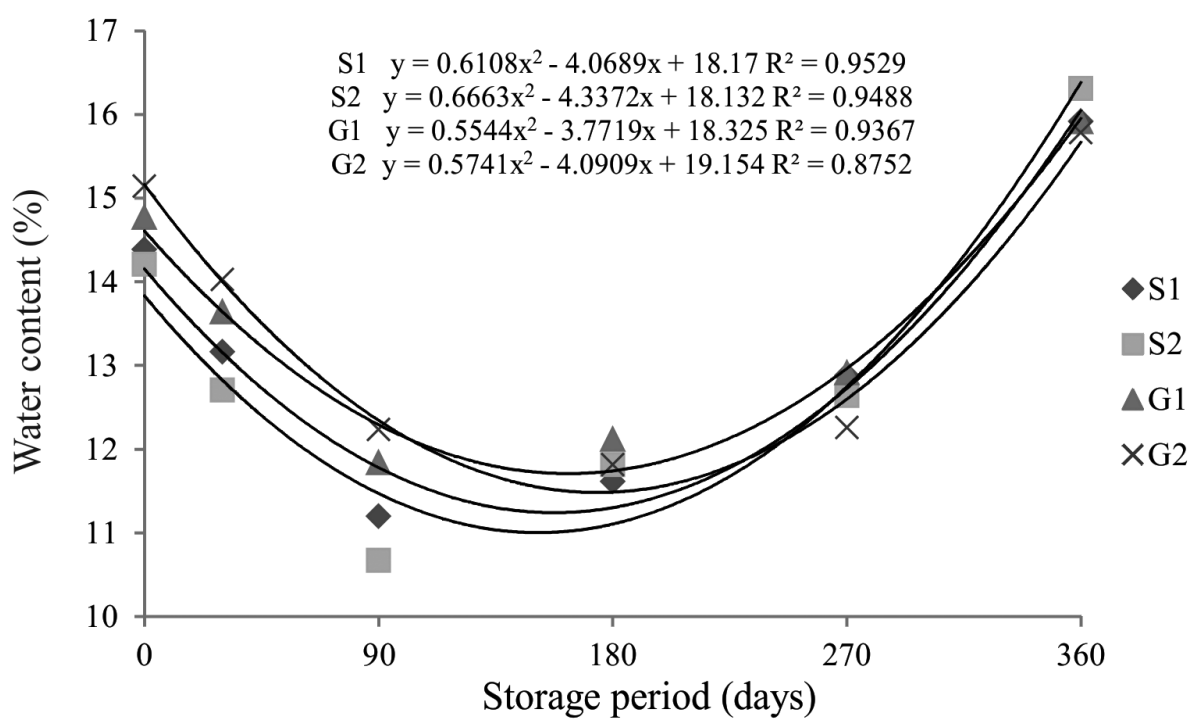

Figure 2 - Significant regression model to water content data of beans seeds (S1 and S2) and grains (G1 e G2), of variety BRS Splendor, during storage periods. Cascavel, PR-2013

statistically until the end of the study, when showed, on average, $16 \%$ of water content. According to Marcos Filho (2005), the seed physiologically behavior is affected by water vapor of atmospheric air, and so, the water content increase with relative humidity and vice-versa. In this study, oscillation of water content in relation to relative humidity modifications of storage period was observed (Figure 1), showing this water vapor exchange capacity to reach hygroscopic balance.

This water content variation was found by Santos et al. (2005) for bean varieties, TPS Beautiful; TPS Noble; Macotaço, IAPAR 44 and TS Bionoble stored in natural conditions, by Cassol et al. (2012) for cultivar IPR Tangará stored for 90 days, on the same environmental conditions and finally by Avaci et al. (2010) on Uirapuru and Red river varieties, submitted by accelerated aging for 30 days.

The initial analysis of germination test indicated lower quality of G1 (Table I), which persisted until the end of the experiment with $74 \%$ germination. From the second evaluation period ( 90 days) differences on the germination potential were showed and by 360 days of storage the classification of physiological quality between beans was possible, S2 and G2 kept high germination percentage.

As presented on Table I, GVI showed similarity until 180 days of storage, followed by a significant decrease after this period; S1 and G1 were lower during all the experiment, the same tendency was observed on the germination test, which confirm the loss of quality of storage beans.

The difference observed between the two areas could be because of environmental conditions of the time of the harvest. On field 2 (low precipitation and $\pm 70 \%$ UR) and on field 1 (after rain period and $\pm 90 \%$ UR), factors that affected initial humidity and beans quality. On field, the seeds are influenced by environment, being susceptible to adverse conditions (Coimbra et al. 2009). The similarity between grains and seeds from the same location can be explained by the fact that the seeds production area border have been intended to consumption (grain), as established by Agriculture Ministry (Brasil 2011).

Germination bean reduction, during storage, have already been reported by several researchers for the varieties: PS Beautiful, TPS Noble, 
TABLE I

Germination percentage and germination velocity index (GVI) of bean seeds (S) and grains (G), of field 1 and 2, of BRS Splendor variety, during storage periods. Cascavel, PR-2013.

\begin{tabular}{|c|c|c|c|c|c|c|}
\hline \multirow{2}{*}{ Beans } & \multicolumn{6}{|c|}{ Storage periods(days) } \\
\hline & 0 & 30 & 90 & 180 & 270 & 360 \\
\hline & \multicolumn{6}{|c|}{ Germination test (\%) } \\
\hline $\mathrm{S} 1$ & $99 \mathrm{aA}$ & $98 \mathrm{abAB}$ & $96 \mathrm{bAB}$ & $95 \mathrm{bBC}$ & $87 \mathrm{bCD}$ & $86 \mathrm{cD}$ \\
\hline $\mathrm{S} 2$ & $100 \mathrm{aA}$ & $100 \mathrm{aA}$ & $100 \mathrm{aA}$ & $100 \mathrm{aA}$ & $96 \mathrm{aA}$ & $99 \mathrm{aA}$ \\
\hline G1 & $94 \mathrm{bA}$ & $95 \mathrm{bA}$ & $92 \mathrm{bAB}$ & $89 \mathrm{bAB}$ & $85 \mathrm{bBC}$ & $74 \mathrm{dC}$ \\
\hline G2 & $100 \mathrm{aA}$ & $100 \mathrm{aA}$ & $100 \mathrm{aA}$ & $100 \mathrm{aA}$ & $99 \mathrm{aA}$ & $93 \mathrm{bB}$ \\
\hline \multicolumn{7}{|l|}{ CV1 $4.47 \%$} \\
\hline \multicolumn{7}{|l|}{ CV2 $4.83 \%$} \\
\hline & \multicolumn{6}{|c|}{ GVI } \\
\hline S1 & $47.4 \mathrm{bA}$ & $47.0 \mathrm{bA}$ & $46.5 \mathrm{bA}$ & $45.3 \mathrm{bA}$ & $38.7 \mathrm{bB}$ & $22.2 \mathrm{bC}$ \\
\hline $\mathrm{S} 2$ & $48.2 \mathrm{aA}$ & $48.3 \mathrm{aA}$ & $48.7 \mathrm{aA}$ & $48.3 \mathrm{aA}$ & $44.6 \mathrm{aB}$ & $25.0 \mathrm{aC}$ \\
\hline G1 & $41.1 \mathrm{cA}$ & $43.1 \mathrm{cA}$ & $42.4 \mathrm{cA}$ & $39.5 \mathrm{cA}$ & $38.5 \mathrm{cB}$ & $18.9 \mathrm{cC}$ \\
\hline G2 & $48.0 \mathrm{aA}$ & $47.9 \mathrm{aA}$ & $47.9 \mathrm{aA}$ & $47.5 \mathrm{aA}$ & $46.7 \mathrm{aB}$ & $23.6 \mathrm{aC}$ \\
\hline CV1 $2.07 \%$ & & & & & & \\
\hline CV2 $2.38 \%$ & & & & & & \\
\hline
\end{tabular}

Means followed by case letter: comparison between columns and rows differ between them by Tukey test ( $5 \%$ of significance). S1 and G1 seeds and grains from field 1, S2 and G2 seeds and grains from field 2, respectively.

Macotaço, IAPAR 44 and TPS Bionoble (Santos et al. 2005); Corujinha and Emepa 1 (Almeida et al. 2009); 94 lineages of Phaseolus vulgaris L. (Maia et al. 2011); IPR Tangará (Cassol et al. 2012) and IPR-TIZIU (Silva et al. 2012) and is related to aging and decrease in its physiological potential. Similar results were also observed on other species, such as soy (Fessel et al. 2010), cotton, peanut, soy, sunflower, castor beans (Almeida et al. 2010) rice and maize seeds (Silva et al. 2010).

For the significant regression model (Figure 3 ) of seeds and grains vigor after exposition to accelerated aging test, it can be verified that although the decrease on germination potential have been observed on all beans, those from field 2 showed more viability. G1 suffered bigger influence under heat stress, having decreased germination from $91 \%$ to $50 \%$, indicating its lower quality. Until 90 days of storage, after being stressed, the index was kept; however, after 270 days this variable dropped significantly, indicating decrease of vigor.

The GVI of beans submitted to heat stress (Figure 3) suffered interaction during the experi- ment, being G1 the sample that was most affected by storage. The values of this variable were stable until 90 days of storage. After this period, S2 and G2 had the biggest index, followed by S1 and G1, indicating a direct relation with beans vigor.

Silva et al. (2012), using the same beans test, found significant decrease in vigor after one year of experiment, maybe due the bigger time of exposition to the test $\left(42{ }^{\circ} \mathrm{C}\right.$ for 72 horas). But Cassol et al. (2012), after 6 and 12 hours of stress by the accelerated aging test, at $42^{\circ} \mathrm{C}$, were able to distinguish the lots without interference of storage time.

Binotti et al. (2008) showed a more intense decrease in beans vigor after 72 hours of heat exposition. Also Avaci et al. (2010) saw this decrease and found that, with 15 and 30 days of accelerated aging at $40{ }^{\circ} \mathrm{C}$ and $76 \%$ de UR, the vigor was null. As well as Bertolin et al. (2011) who verified decrease and increase of the deterioration rate due bigger exposition to the test.

The water content of the beans after exposition to accelerated aging test remain about $24 \%$ for time 0 and $30,22 \%$ for 90,180 and 270 and $23 \%$ for 360 

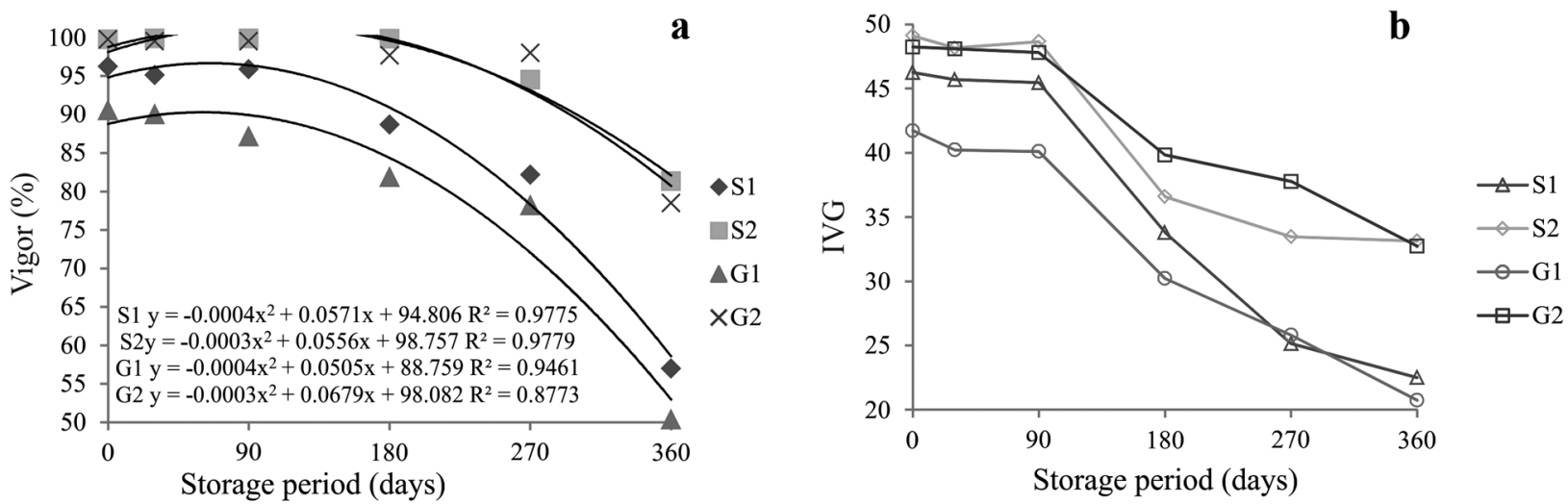

Figure 3 - Significant regression model to vigor by accelerated aging test of 24 hours (a), and germination velocity index (b) of beans seeds and grains, of BRS Splendor variety, during storage periods. S1 and G1 seeds and grains from field 1, S2 and G2 seeds and grains from field 2, respectively Cascavel, PR-2013

days of storage. The similarity between the beans is desirable, since it proves the uniform conditions of the test execution (Marcos Filho 1999). Similar results were also found by Toledo et al. (2009) in beans of Pearl cultivar, by Bertolin et al. (2011) who observed differences lowers than $4 \%$ between tested samples of beans and also by De Bittencourt et al. (2012) between the maize lots studied.

As showed in Figure 4, when submitted to cold stress, S1 and G1 were more sensitive. In grains (G1), the initial $93 \%$ dropped to $76 \%$ on final vigor. There was no statistically difference on vigor until 180 days of storage. After this period, this variable decreased for the beans from the two fields.

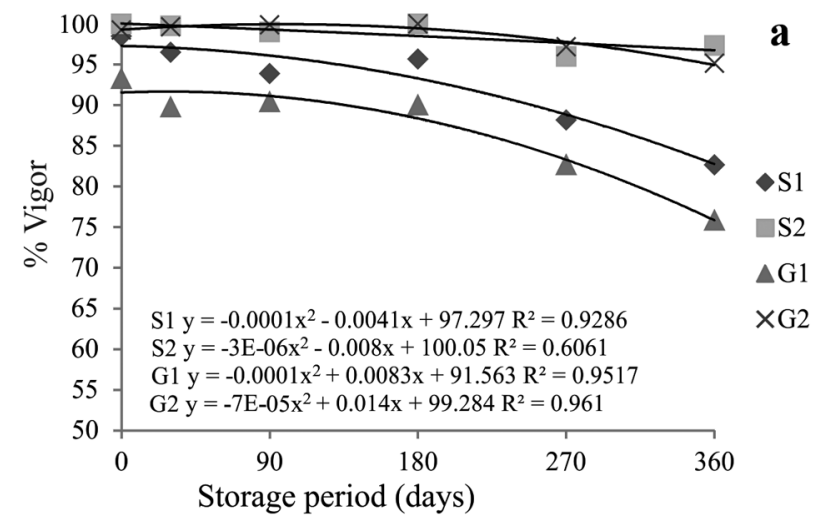

Results that support with Fessel et al. (2006), which observed decrease on maize seeds vigor submitted to the same stress after 4 months of storage. Also Fessel et al. (2010) detected an initial difference between soy seeds studied and after three months the less vigorous lots showed significantly reduction of this variable, while on other the decrease was more gradually. So Guiscem et al. (2010), evaluating cowpea seeds, by cold test without soil, were able to identify different vigor levels between studied materials.

It can be observed on Figure 4 that G1 shows lower values, being statistically different than the others. In evaluation period oscillations were

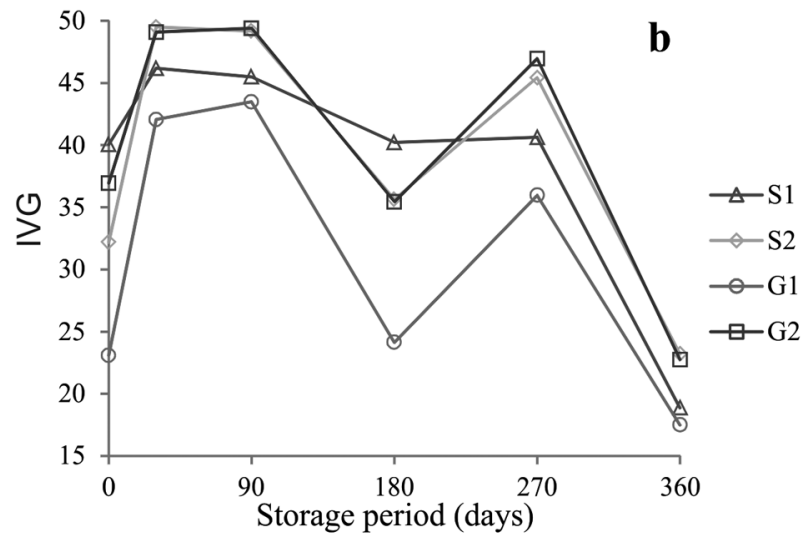

Figure 4 - Significant regression model to vigor by cold test (a), and germination velocity index (b) of beans seeds and grains, of BRS Splendor variety, during storage periods. S1 and G1 seeds and grains from field 1, S2 and G2 seeds and grains from field 2, respectively Cascavel, PR-2013 
noticed until 270 days, with a drop on GVI of all beans, at the last analyze. The cold test didn't show the same tendency of GVI, however, the vigor dropped substantially.

The GVI of the tests performed showed decrease during experiment, indicating a reduction on beans vigor because of the storage, agreeing with the study performed by Cardoso et al. (2012) on crambe seeds, whose GVI (from the germination test) decreased with the storage in a conventional package. Marcos Filho (2005) commented that the seed aging results in a decrease of the physiological potential: a reduction in the germination capacity and an increase of environmental stress sensibility occurs.

The average length of aerial part (Table II), of beans seedlings studied suffered interaction throughout the study. The G1 ALAP decreased while the others had oscillations along the experiment. G2 suffered bigger variation during storage, while S1 did not show variation at all.

Seedlings with bigger aerial part and root length derived from vigorous seeds were observed in soy seeds by Vanzolini and Carvalho (2002), when evaluating the effect of lots with different vigor on the emergence in field and by Henning et al. (2010), by evaluating the chemical composition and the reserve mobilization in low vigor seeds. Such affirmation are confirm by the GVI results showed in this work.

The ARL of G1 decreased (Table II), while the others showed variations along the experiment; however, can be observed the statistically similarity between seeds and grains. All of them were influenced by storage, which caused varied lengths between the periods. Santos et al. (2005) observed reduction in this parameter, an average of $40-50 \%$, in their study. While, in Cassol et al. (2012) study, the average length of root showed difference between the lots and by 90 days of storage an increase was noticed.

The storage period of 360 days under natural conditions, affected the physiological behavior of seeds and grains tested.

The accelerated aging tests, cold and GVI were the most sensitive in the detection of vigor

TABLE II

Average length of aerial part (ALAP) and average root length (ARL) after the germination test of beans seeds (S) and grains (G), of fields 1 and 2, of the BRS Splendor variety. Cascavel, PR-2013.

\begin{tabular}{|c|c|c|c|c|c|c|}
\hline \multirow{2}{*}{ Beans } & \multicolumn{6}{|c|}{ Storage periods (days) } \\
\hline & 0 & 30 & 90 & 180 & 270 & 360 \\
\hline & \multicolumn{6}{|c|}{$\operatorname{ALAP}(\mathrm{cm})-$ Germination } \\
\hline $\mathrm{S} 1$ & $11.59 \mathrm{aA}$ & $11.19 \mathrm{aA}$ & $10.38 \mathrm{aA}$ & $10.55 \mathrm{aA}$ & $10.79 \mathrm{abA}$ & $10.66 \mathrm{aA}$ \\
\hline $\mathrm{S} 2$ & $10.47 \mathrm{abAB}$ & $11.10 \mathrm{aA}$ & $10.88 \mathrm{aA}$ & $9.28 \mathrm{aB}$ & $11.17 \mathrm{abA}$ & $11.03 \mathrm{aA}$ \\
\hline G1 & $11.38 \mathrm{abA}$ & $10.90 \mathrm{aA}$ & $10.28 \mathrm{aAB}$ & $10.27 \mathrm{aAB}$ & $10.09 \mathrm{bAB}$ & $8.82 \mathrm{bB}$ \\
\hline G2 & $9.88 \mathrm{bB}$ & $11.59 \mathrm{aA}$ & $11.00 \mathrm{aAB}$ & $9.80 \mathrm{aB}$ & $11.87 \mathrm{aA}$ & $9.77 \mathrm{abB}$ \\
\hline \multicolumn{7}{|l|}{ CV1 $4.89 \%$} \\
\hline \multicolumn{7}{|l|}{ CV2 $3.48 \%$} \\
\hline & \multicolumn{6}{|c|}{ ARL $(\mathrm{cm})-$ Germination } \\
\hline $\mathrm{S} 1$ & $10.55 \mathrm{bBC}$ & $13.02 \mathrm{aA}$ & $11.86 \mathrm{aAB}$ & $10.96 \mathrm{aAB}$ & $10.61 \mathrm{aBC}$ & $8.56 \mathrm{bcC}$ \\
\hline $\mathrm{S} 2$ & $12.73 \mathrm{aA}$ & $12.75 \mathrm{aA}$ & $12.75 \mathrm{aA}$ & $11.48 \mathrm{aAB}$ & $9.61 \mathrm{aB}$ & $10.66 \mathrm{aAB}$ \\
\hline G1 & $12.22 \mathrm{abA}$ & $11.54 \mathrm{aA}$ & $11.53 \mathrm{aA}$ & $10.46 \mathrm{aA}$ & $10.41 \mathrm{aA}$ & $7.77 \mathrm{cB}$ \\
\hline G2 & $11.48 \mathrm{abAB}$ & $13.02 \mathrm{aA}$ & $12.10 \mathrm{aAB}$ & $12.41 \mathrm{aAB}$ & $11.28 \mathrm{aAB}$ & $10.37 \mathrm{abB}$ \\
\hline CV1 $5.35 \%$ & & & & & & \\
\hline CV2 $4.53 \%$ & & & & & & \\
\hline
\end{tabular}

Means followed by case letter: comparison between columns and rows differ between them by Tukey test ( $5 \%$ of significance). S1 and G1 seeds and grains from field 1, S2 and G2 seeds and grains from field 2, respectively. 
decrease, more apparent on beans from field 1 which showed lower initial physiological quality.

\section{ACKNOWLEDGMENTS}

The authors would like to acknowledge Coordenação de Aperfeiçoamento de Pessoal de Nível Superior (CAPES) for their financial support during the execution of this research.

\section{RESUMO}

O feijão é um dos alimentos utilizados para suprir as necessidades energéticas da dieta dos brasileiros, sendo necessário que os agricultores utilizem sementes de alto potencial fisiológico. O objetivo foi avaliar a qualidade fisiológica de feijões armazenados por 360 dias. As análises foram realizadas nos tempos $0,30,90,180,270$ e 360 dias após a recepção das sementes (S1 e S2) e grãos (G1 e G2) da cultivar BRS Esplendor. Foram realizados os testes de germinação, envelhecimento acelerado, frio, índice de velocidade de germinação, comprimento médio da parte aérea e raiz. O delineamento utilizado foi inteiramente casualizado em parcelas subdivididas no tempo e as médias comparadas pelo teste de Tukey, ao nível de $5 \%$ de probabilidade. A germinação das sementes não foi afetada para S2, enquanto que para $\mathrm{S} 1$ e G1 a queda foi significativa. O vigor dos grãos do campo 1 declinou de 91 para $50 \%$ e de 93 para $76 \%$, pelos testes de envelhecimento acelerado e a frio, respectivamente, após 360 dias. O índice de velocidade dos testes de germinação realizados apresentou queda durante o experimento. Os grãos do campo 1 apresentaram menor qualidade fisiológica. Os testes de envelhecimento acelerado e frio, através do parâmetro índice de velocidade de germinação, evidenciaram a queda do vigor da cultivar BRS Esplendor. O período de armazenamento influenciou a qualidade fisiológica dos feijões testados.

Palavras-chave: germinação, Phaseolus vulgaris L., qualidade fisiológica, vigor.

\section{REFERENCES}

ALMEIDA FAC, CAVALCANTI MFBS, SANTOS JF, GOMES JP AND NETO JJSB. 2009. Viabilidade de sementes de feijão macassar tratadas com extrato vegetal e acondicionadas em dois tipos de embalagens. Acta Sci Agron 31: 345-351.
Almeida FAC, JERÔNIMO ES, MARrize N, Alves C, GOMES JP AND SILVA AS. 2010. Estudo de técnicas para o armazenamento de cinco oleaginosas em condições ambientais e criogênicas. Rev Bras Prod Agroind 12: 189202.

AVAci AB, COELHO SRM, NÓBREGA LHP, ROSA DM AND CHRIST D. 2010. Qualidade fisiológica de sementes de feijão envelhecidas em condições de alta temperatura e umidade relativa. Publ UEPG Ci Exatas Terra. Ci Agr Eng 16: 33-38.

BANZATTO DA AND KRONKA SN. 1995. Experimentação agrícola, $3^{\mathrm{a}}$ ed., Funep. Jaboticabal, 247 p.

BARROSASR, DIAS MCLL, CÍCEROSM AND KRZYZANOWSKI FC. 1999. Teste de frio. In: Krzyzanowski FC, Vieira RD and França Neto JB (Eds), Vigor de Sementes: conceitos e testes, Abrates. Londrina, p. 94-108.

BERTOLIN DC, SÁ ME AND MOREIRA ER. 2011. Parâmetros do teste de envelhecimento acelerado para determinação do vigor de sementes de feijão. Rev Bras Sementes 33: 104-112.

BinotTi FFS, Haga KI, CARdoso ED, Alves CZ, SÁ ME AND ARF O. 2008. Efeito do período de envelhecimento acelerado no teste de condutividade elétrica e na qualidade fisiológica de sementes de feijão. Acta Sci Agron 30: 247 254.

BRASIL. 2009. Regras para Análise de Sementes. Brasília: MAPA/ACS, 399 p. http://www.agricultura.gov.br/arq editor/file/2946_regras_analise_sementes.pdf.

BRASIL. 2011. Guia de Inspeção de Campos para Produção de Sementes, $3^{a}$ ed., Brasília: Mapa/ACS, 41 p. http:// www.agricultura.gov.br/arq_editor/file/3494_guia_de_ inspecao_sementes.pdf.

CARdoso RB, BINOTTI FFS AND CARdoso ED. 2012. Potencial físiológico de sementes de crambe em função de embalagens e armazenamento. Pesq Agropec Trop 42: 272-278.

CARVALHO NM AND NAKAGAWA J. 2000. Sementes: Ciência, tecnologia e produção, $4^{\text {a }}$ ed., Funep/Unesp. Jaboticabal.

CASSOL FDR, FORTES AMT, NUNES JVD, VEIT MR AND CRUZ M. 2012. Qualidade fisiológica de lotes de sementes de feijão em função do armazenamento. Cultivando o Saber 5: 85-97.

COIMBRA RA, MARTINS CC, TOMAZ CA AND NAKAGAWA J. 2009. Testes de vigor utilizados na avaliação da qualidade fisiológica de lotes de sementes de milho-doce (sh2). Cienc Rural 39: 2402-2408.

CONAB - COMPANHIA NACIONAL DE ABASTECIMENTO. 2012. Disponível em: http://www.conab.gov.br/ OlalaCMS/uploads/arquivos/12_01_10_10_53_02 boletim_graos_4o_levantamento.pdf. Acessado em 20 de agosto de 2012.

DE BITTENCOURT SRM, GRZYBOWSKI CRS, PANOBIANCO M AND VIEIRA RD. 2012. Metodologia alternativa para 
condução do teste de envelhecimento acelerado em sementes de milho. Cienc Rural 42: 1360-1365.

FERREIRA DF. 2008. Sisvar: um programa para análises e ensino de estatística. Rev Cient Symposium 6: 36-41.

FEssel AS, PANOBIANCO M, SOUZA CR AND VIEIRA RD. 2010. Teste de condutividade elétrica em sementes de soja armazenadas sob diferentes temperaturas. Bragantia 69: 207-214.

FESSEL AS, VIEIRA RD, CRUZ MCP, PAUla RC AND PANOBIANCO M. 2006. Electrical conductivity testing of corn seeds as influenced by temperature and period of storage. Pesq Agropec Bras 41: 1551-1559.

Guiscem JM, FARIAS AS, DE FigueIREdo RT, CHAVES AMS, DE FIGUEIREDO BT, PEREIRA CF, ARAÚJO JRG AND MARTINS MR. 2010. Teste de frio e envelhecimento acelerado na avaliação de vigor de sementes de feijãofrade. Rev Cienc Agrárias 33: 182-191.

HENNING FA, MERTZ LM, JACOB-JUNIOR EA, MACHADO RD, FISS G AND ZIMMER PJ. 2010. Composição química e mobilização de reservas em sementes de soja de alto e baixo vigor. Bragantia 69: 727-734.

MAGUIRE JD. 1962. Seeds of germination-aid selection and evaluation seedling emergence and vigor. Crop Science 2: $176-177$.

MAIA LGS, Silva CA, RAMAlHo MAP AND ABREU AFB. 2011. Variabilidade genética associada à germinação e vigor de sementes de linhagens de feijoeiro comum. Cienc Agrotec 35: 361-367.

MARCOS-FILHO J. 1999. Teste de envelhecimento acelerado. In: Krzyzanowski FC, Vieira RD and França Neto JB (Eds), Vigor de Sementes: conceitos e testes, Abrates. Londrina, p. 46-67.

MARCOS-FILHO J. 2005. Fisiologia de Sementes de plantas cultivadas. Fealq, Piracicaba, 495 p.

Miguel MH AND CICERO SM. 1999. Teste de frio na avaliação do vigor de sementes de feijão. Scien Agric 56: 12331243.

NAKAGAWA J. 1999. Testes de vigor baseados no desempenho das plântulas. In: Krzyzanowski FC, Vieira RD and França
Neto JB (Eds), Vigor de Sementes: conceitos e testes, Abrates. Londrina, p. 22-45.

PALABIYIK B AND PEKSEN E. 2008. Effects of seed storage periods on electrical conductivity of seed leakage, germination and field emergence percentage in common bean (Phaseolus vulgaris L.). Asian J Chem 20: 30333041.

R DeVElopment CoRe TEAM. 2011. R: A language and environment for statistical computing. R Foundation for Statistical Computing, Vienna, Austria. ISBN 3-90005107-0, URL http://www.R-project.org/.

RESENDE O, CORRÊA PC, FARONI LRA AND CECON PR. 2008. Avaliação da qualidade tecnológica do feijão durante o armazenamento. Ciênc Agrotec 32: 517-524.

RIGUEIRA RJA, LACERDA FILHO AF AND VOLK MB. 2009. Avaliação da qualidade do feijão armazenado em ambiente refrigerado. Rev Alim Nutri 20: 649-655.

SANTOS CMR, MENEZES NL AND VILLELA FA. 2005. Modificações fisiológicas e bioquímicas em sementes de feijão no armazenamento. Rev Bras Sementes 27: 104-114.

SILVA CD, PAZETO MSR AND VIEIRA RD. 2012. Electrical conductivity and mineral composition of the Imbibition solution of bean seeds during storage. Ciênc Agrotec 36: 147-155.

Silva FS, PORTO AG, PASCUAli LC AND Silva FTC. 2010. Viabilidade do armazenamento de sementes em diferentes embalagens para pequenas propriedades rurais. Rev Ciênc Agroamb 8: 45-56.

SOARES MM, CONCEIÇÃO PM, DIAS DCFS AND ALVARENGA EM. 2010. Testes para avaliação do vigor de sementes sorgo com ênfase à condutividade elétrica. Ciênc Agrotec 34: 391-397.

TOLEDO MZ, FONSECA NR, CESAR ML, SORATTO RP, CAVARIANI C AND CRUSCIOL CAC. 2009. Qualidade fisiológica e armazenamento de sementes de feijão em função da aplicação tardia de nitrogênio em cobertura. Pesq Agropec Trop 39: 124-133.

VANZOLINI S AND CARVALHO NM. 2002. Efeito do vigor de sementes de soja sobre o seu desempenho em campo. Rev Bras Sementes 24: 33-41. 